\title{
IMPLEMENTASI OLESAN JERUK NIPIS(CITRUS AURANTIFOLIA) UNTUK MENGURANGI STRIAE GRAVIDARUM DAN KELANGSINGAN PERUT PADA IBU NIFAS
}

\author{
Yuniar Angelia Puspadewi ${ }^{1)}$, Uswatun Chasanah ${ }^{2)}$ \\ Prodi Kebidanan STIKES Widyagama Husada \\ 1)yuniar80@yahoo.co.id \\ 2) uswatun.chasanah90.uc@gmail.com
}

\begin{abstract}
Lime is a fruit that contains lots of vitamins, and minerals. Lime contains a lot of useful nutrients for health and disease prevention and has lots of vitamin $C$ that works for endurance. Lime also is an antioxidant that functions to delay the premature aging (anti-aging) and to lean postpartum. In the postpartum, the strie gravidarum occurs during the pregnancy makes women become not confident. This makes them try to find ways to eliminate Strie gravidarum and create a slimming tummy after child birthing. This study aimed at finding out the effectiveness of lime (Citrus aurantifolia) to decrease the Strie gravidarum and create a slimming tummy to women in postpartum. The pretest and posttest technique was conducted. Subjects in this study were the first day of postpartum women. Fat thickness measurement and documentation of striae gravidarum were done on the first day of postpartum. The treatments were cone by applying lime extract every day (morning and evening) for 3 weeks. After 3 weeks, measurement and documentation were done again to know whether there was reduction in fat thickness and striae gravidarum or not. The results showed that most of Strie gravidarum reduced after the treatment. Based on the analysis of chi square count $T>T$ Ha was valid, so that it can be concluded that the regularity of applying the lime extract can reduce Strie gravidarum. T-test analysis obtained from $T$ count $>T$ table shows that there is a difference between thick stomach and abdominal circumference before and after the lime applied. The use of lime regularly and properly is effective to decrease striae on the abdomen slimming gravidarun and puerperal women.
\end{abstract}

Keywords: Lime, Striae gravidarum, Postpartum, Slim 


\section{Abstrak}

Jeruk adalah buah-buahan yang berguna bagi kesehatan dan pencegahan penyakit dan banyak mengandung vitamin c yang berfungsi untuk daya tahan tubuh. Jeruk juga dapat berfungsi sebagai antioksidan, dimana antioksidan tersebut berguna untuk menunda penuaan dini (awet muda) dan juga untuk pelangsingan perut pasca melahirkan. Dalam masa nifas, terjadi kekendoran perut dan strie gravidarum yang timbul pada masa kehamilan sehingga mengakibatkan ibu tidak percaya diri akan perubahan pada daerah perutnya. Hal ini membuat ibu-ibu mencari berbagai cara/alternative untuk menghilangkan strie gravidarum dan melangsingkan perut setelah melahirkan. Tujuan penelitin ini adalah untuk mengetahui apakah olesan jeruk nipis (Citrus Aurantifora) dapat mengurangi striae gravidarum dan melangsingkan perut ibu nifas. Metode yang dilakukan dengan teknik pretest-postest one-group design. Subjek dalam penelitian ini adalah ibu nifas hari pertama. Pengukuran ketebalan lemak dan dokumentasi striae gravidarum dilakukan ketika ibu nifas hari ke-1. Perlakuan olesan jeruk nipis setiap hari (pagi dan sore hari) selama 3 minggu. Setelah 3 minggu, ketebalan lemak diukur dan didokumentasikan kembali untuk mengetahui apakah ada pengurangan ketebalan lemak dan striae gravidarum. Sebagian besar strie gravidarum berkurang setelah diberikan oles perasan jeruk nipis. Berdasarkan hasil analisa chi kuadrat $\mathrm{T}$ hitung > T tabel maka Ha diterima sehingga dapat disimpulkan bahwa keteraturan pemberian oles perasan jeruk nipis dapat mengurangi strie gravidarum. Dari analisa uji $\mathrm{T}$ didapatkan $\mathrm{T}$ hitung $>\mathrm{T}$ tabel, hal ini menunjukkan bahwa terdapat perbedaan antara tebal perut dan lingkar perut sebelum dan setelah pemberian oles jeruk nipis. Kesimpulannya adalah olesan jeruk nipis sangat efektif dalam menghilangkan striae gravidarun dan melangsingkan perut pada ibu nifas dengan pemberian secara benar dan teratur.

\section{Kata Kunci : Jeruk nipis, Kelangsingan Perut, Striae Gravidarum, Ibu Nifas}

\section{PENDAHULUAN}

Seorang
kehidupannya akan mengalami
tahapan-tahapan reproduktif mulai
dari menstruasi, hamil, melahirkan,
sampai tahap menopause. Salah satu
proses yang dialami seorang wanita adalah proses nifas (Bobak,2004). Perawatan masa nifas ini termasuk dalam perawatan kebidanan dimana perawatan kebidanan tidak hanya terbatas pada masa kehamilan dan persalinan tetapi juga masa nifas sampai pulih seperti semula yang semua itu mempunyai tujuan agar kegiatan itu terarah dan terevaluasi. (Sarwono 2009, hal 236)

$$
\text { Hal-hal yang menarik dan }
$$
member ciri masa nifas adalah perubahan-perubahan yang dianggap normal dan harus terjadi untuk memenuhi sebagian dari fungsi masa nifas yaitu mengembalikan keadaan seperti sebelum hamil. Keadaan bentuk tubuh yang dialami ibu setelah melahirkan, terutama pada daerah bagian perut membuat ibu menjadi tidak percaya diri.

Perut ibu yang kendor dan jelek akan dirasakan semua ibu nifas, dimana dalam hal ini ibu sangat bingung dengan bagaimana cara melangsingkan dan menghilangkan garis perut seperti sebelum hamil. Saat ini banyak ibu-ibu nifas yang mengkonsumsi obat diet dan menggunakan stagen yang terlalu kencang, atau bahkan hanya sekedar 
mendengar cerita dari ibu-ibu lainnya sehingga banyak diantara mereka mengkonsumsi obat diet dari pada memakai ramuan alami.

Saat ini cara tradisional untuk memperlangsing ibu nifas banyak ditinggalkan karena dirasa kurang praktis alias ribet, walaupun cara tradisional lebih aman dan tidak ada efek samping. Ada beberapa ramuan alami untuk mengecilkan perut, khususnya mengecilkan perut bagian bawah. Seperti salah satunya adalah pemberian oles jeruk nipis (Anonymus, 2012).

Jika dikaji lebih dalam jeruk nipis (Citrus Aurantifolia) adalah salah satu jenis Citrus Geruk. Jeruk nipis termasuk jenis tumbuhan perduyang banyak memiliki dahan dan ranting yang menghasilkan buah dengan nama sama. Tumbuhan ini dimanfaatkan buahnya, yang biasanya bulat, berwarna hijau atau kuning, memiliki diameter3-6cm, memiliki rasa asam dan agak pahit, agak serupa rasanya dengan lemon. Kandungan jeruk nipis yang sudah banyak kita ketahui adalah kandunganvitamin $\mathrm{C}$ nya yang tinggi dibanding jenis jeruk lainnya. (Sumiati,2007:12)

Ada alternative yang dapat dilakukan dalam melakukan perwatan dengan jeruk nipis untuk penghilang garisan pada perut (strie gravidarum), yaitu dengan menambahkan kapur sirih dan minyak kayu putih dan dioleskan secara merata setiap hari sehabis mandi (Nurheti,2011:136).

Berdasarkan studi pendahuluan di BPM Dillah Sobirin bulan Agustus, terhadap 5 ibu nifas ditemukan 3 orang menggunakan oles jeruk nipis dan 2 orang Ibu nifas tidak menggunakan olesan jeruk nipis dengan tujuan untuk melangsingkan dan menghilangkan garisan pada perutnya. Berdasarkan penjelasan diatas, maka penulis ingin meneliti tentangolesan jeruk nipis (citrus aurantifolia) untuk mengurangi striae gravidarum dan kelangsingan perut pada ibu nifas.

Secara umum penelitian ini bertujuan untuk menganalisis olesan jeruk nipis(citrus aurantifolia)untuk mengurangi striae gravidarum dan kelangsingan perut pada ibu nifas dan secara khusus ditujukan untuk melakukan Identifikasi kelangsingan perut dan striae gravidarum sebelum pemberian olesan jeruk nipis,

Identifikasi kelangsingan perut dan striae gravidarum setelah pemberian olesan jeruk nipis, (3) Menganalisis olesan jeruk nipis(citrus aurantifolia)untuk mengurangi striae gravidarum dan kelangsingan perut pada ibu nifas.

\section{METODE PENELITIAN}

Penelitian ini termasuk dalam jenis penelitian pra-eksperimen dengan menggunakan one-group pretest-posttest desain yaitu desain yang digunakan untuk meneliti pada satu kelompok dengan dilakukan pengukuran dan pendokumentasian terlebih dahulu satu kali kemudian diberi perlakuan (treatment) dan setelah itu dilakukan pengukuran dan pendokumentasian kembali.

Dalam penelitian ini yang diobservasi adalah tebal lemak dan striae gravidarum ibu sebelum diberikan olesan jeruk nipis dan setelah diberi olesan jeruk nipis. Dan dalam desain ini tidak menggunakan kelompok 
kontrol dan kelompok pembanding. Data yang terkumpul dilakukan: editing, coding, scoring, transfering, tabulating, selanjutnya dianalisis statistik dengan program software SPSS 16.

\section{HASIL DAN PEMBAHASAN}

Hasil penelitian yang dilakukan sebelum diberikan oles perasan jeruk nipis pada post partum hari pertama didapatkan bahwa strie livide sebanyak 4 orang $(20 \%)$ dan strie albican sebanyak 16 orang $(80 \%)$ dengan keadaan strie yang sama yaitu banyak dan jelas.

Pada saat sebelum diberikan oles jeruk nipis didapatkan hasil dari pengukuran lingkar perut dan tebal lemak sangat kelihatan, hal ini secara subyektif dapat dilihat dari tebal lemak minimal $20 \mathrm{~mm}$, maksimal $43 \mathrm{~mm}$, rata-rata $28,9500 \mathrm{~mm}$ dan standart devisiasi $6,18551 \mathrm{~mm}$, sedangkan data lingkar perut minimal $70 \mathrm{~cm}$, maksimal $121 \mathrm{~cm}$, rata-rata 91,9000 cm dan standart devisiasi $14,12314 \mathrm{~cm}$.

Setelah diberikan perasan oles jeruk nipis didapatkan hasil dari dari 20 responden, yang rutin memberikan oles jeruk nipis yaitu sebanyak 17 orang (85\%) dan tidak rutin memberikan oles jeruk nipis sebanyak 3 orang (15\%) disebabkan karena ibu lupa. Adapun hasil dari pemberian oles jeruk nipis yang berbeda - beda dari tiap responden yaitu terdapat ada 16 orang $(80 \%)$ yang mengalami pengurangan strie gravidarum setelah pemberian oles jeruk nipis sedangkan ada 4 orang $(20 \%)$ yang tidak mengalami pengurangan strie gravidarum setelah pemberian oles jeruk nipis. Responden yang tidak mengalami pengurangan pada strie gravidarum disebabkan karena cara pengolesan jeruk nipis yang tidak merata dan terlalu tipis.

Pada saat setelah diberikan oles jeruk nipis didapatkan hasil dari pengukuran lingkar perut sebelum diberikan oles jeruk nipis lingkar perut minimal $59 \mathrm{~cm}$, maksimal 110 $\mathrm{cm}$, rata-rata $80,9500 \mathrm{~cm}$ dan standart devisiasi 14,54747 $\mathrm{cm}$ dan tebal lemak sebelum diberikan oles jeruk nipis rata-rata rata-rata $28,95000 \mathrm{~mm}$ dan tebal lemak setelah pemberian oles jeruk nipis rata-rata 15,6000 mm.

Berdasarkan hasil analisa diatas menunjukkan bahwa $\operatorname{sig}<\alpha \quad(0,05)$ artinya $\mathrm{H} 0$ ditolak dan $\mathrm{H} 1$ diterima dengan hasil chi square 0,000 Sehingga dapat disimpulkan bahwa pemberian oles perasan jeruk nipis secara teratur dapat mengurangi strie gravidarum pada ibu post partum.

Hasil analisa data terhadap efektifitas oles jeruk nipis terhadap kelangsingan perut ibu nifas diambil dari data di BPM Dillah Sobirin Wilayah Malang. Sedangkan dari analisa data menggunakan menggunakan uji Paired $t$ - Test didapatkan hasil $\mathrm{t}$ hitung $>\mathrm{t}$ tabel, dan $\alpha<0,05$ yaitu 0,00 maka $\mathrm{H}_{0}$ ditolak $\mathrm{H}_{1}$ diterima artinya ada efektifitas pemberian oles jeruk nipis terhadap pengembalian kelangsingan perut ibu nifas.

Hasil analisa data terhadap efektifitas oles jeruk nipis terhadap kelangsingan perut ibu nifas diambil dari data di BPM Dillah Sobirin Wilayah Malang. Sedangkan dari analisa data menggunakan menggunakan uji Paired t-Test didapatkan hasil $\mathrm{t}$ hitung $>\mathrm{t}$ tabel, dan $\alpha<0,05$ yaitu 0,00 maka $\mathrm{H}_{0}$ ditolak $\mathrm{H}_{1}$ 
diterima artinya ada efektifitas pemberian oles jeruk nipis terhadap pengembalian kelangsingan perut ibu nifas.

Pengurangan strie pada ibu dikarenakan tata cara penggunaan oles jeruk nipis yang benar dan teratur dalam pemberiannya. Cara pemberian oles jeruk nipis yaitu peras jeruk nipis dan ukur dalam gelas ukur hingga 2,5 cc kemudian oleskan secara merata pada strie gravidarum serta lakukan secara rutin pada pagi dan sore hari setelah mandi.

Ibu postpartum sebagai responden dalam penelitian ini adalah ibu postpartum hari pertama dikarenakan jika postpartum lebih dari 5 hari maka keadaan strie telah berubah. Postpartum merupakan pengembalian alat-alat kandungan seperti sebelum hamil (Saifuddin, 2006: 122).

Mekanisme kerja jeruk nipis yaitu sari buah jeruk nipis merupakan diuretik alami yang lezat. Jeruk nipis melarutkan lemak yang menumpuk di sel-sel, menghancurkannya, kemudian membuangnya keluar, menurut $B$. Sarwono (2004). Jeruk nipis dapat merangsang/menghancurkan lemak yang ada diperut sehingga mengembalikan kelangsingan perut ibu nifas. Dan pengembalian kelangsingan perut ibu tersebut juga dikarenakan dari tata cara penggunaan oles jeruk nipis yang benar dan teratur yaitu jeruk nipis dioleskan keperut sampai kepunggung tunggu sampai kering kemudian dipakai stagen/ambat, digunakan waktu pagi dan sore selama 3 minggu.
Menurut James Diugan (2012) setelah melahirkan, biasanya rahim akan menurun dan menjadi lebih berat dari pada sebelumnya. Ibu nifas yang menjadi subjek dalam penelitian ini yaitu ibu nifas hari 1-20. Hal ini dikarenakan jika lebih dari 20 hari kekendoran perut ibu nifas sudah agak kembali dan tidak kelihatan.

\section{KESIMPULAN}

Ada perbedaan yang signifikan antara lingkar perut dan tebal lemak sebelum dan setelah pemberian oles jeruk nipis pada ibu nifas. Ada 17 responden $(85 \%)$ yang rutin memberikan oles jeruk nipis, 16 responden $\quad(94,1 \%)$ diantaranya mengalami pengurangan dan $1(5,88 \%)$ responden tidak mengalami pengurangan. Sedangkan dari 3 responden (15\%) yang tidak rutin memberikan oles perasan jeruk nipis ketiganya $(100 \%)$ tidak mengalami pengurangan pada strie gravidarum.

\section{SARAN}

Hasil penelitian ini diharapkan dapat memberikan informasi kepada ibu nifas terutama pada ibu nifas fisiologis bahwa olesan jeruk nipis sangat efektif dalam mengurangi striae gravidarum dan kelangsingan perut dengan cara pemberiannya secara rutin dan merata.

\section{DAFTAR PUSTAKA}

Abdul,bari. 2006. Konsepdasar masanifas. Jakarta: EGC

Anna. 2012. Khasiat dan Manfaat Jeruk Nipis. Surabaya: Stomata.

Anonimus. 2012. Teori Nifas Post Partum Blus. http:// rohman-fitria blog spot.com/2010/07/landasan- teori- 
nifas.html.

Anonimus. 2012. Aroma Jeruk Nipis. http://www.facebook.com/notes/ modena- cooking-club/ jenis-danmanfaat- jeruk-bagi- tubuh.

Anonimus. 2012. Jenis-jenis Manfaat Jeruk. ～～（http://www.Tanya pepsoden.com/ aroma -jeruknipis).

Anonimus. 2012. Manfaat Jeruk Nipis. http://www.Permenkopibogsportnotes.com/2012/06/khasia t-manfaat-jeruk-nifis-part $1 \mathrm{html}$.

Anonimus. 2012. PengertianJeruk. http://skasen.blogspot.com.

Anonymus. 2010. Pengertian Strie Gravidarum. www.zomtemplate. com. Diakses pada 16 Maret 2013.

Anonymus. 2010. Strachmark. www.Hyperlinkreference.com. Diakses pada 16 Maret 2013.

Anonymus. 2011. Strie Gravidarum. www.mediasehat.com. Diakses pada 17 Maret 2013.

Anonymus. 2012. Obstetrics and gynaecology. www.jurnal.com. Diakses pada 20 Juni 2013.

Anonymus. 2013. Penyebab stracmark. www.mayoclinic.com. Diakses pada 17 Maret 2013.

Eny Retna Ambarwati, dkk. 2010. Asuhan Kebidanan Nifas. Jogjakarta: Nuha Medika.

Hidayat, A. A. 2010. Metode Penelitian Kesehatan Paradigma Kuantitatif. Surabaya: Health Books Publishing.

Karina, A. 2012. Jeruk Nipis. Surabaya: Stomata 